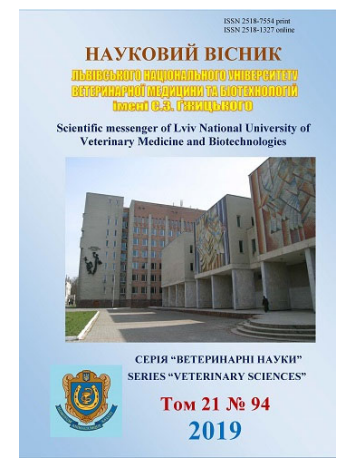

\author{
Науковий вісник Аьвівського національного університету \\ ветеринарної медицини та біотехнологій імені С.3. Гжицького. \\ Серія: Ветеринарні науки \\ Scientific Messenger of Lviv National University \\ of Veterinary Medicine and Biotechnologies. \\ Series: Veterinary sciences
}

\title{
Influence of varroosic invasion on wintering of bee colonies
}

\author{
O.S. Nazarenko \\ Poltava State Agrarian Academy, Poltava, Ukraine
}

Article info

Received 06.05.2019 Received in revised form 07.05 .2019

Accepted 06.06.2019

Poltava State Agrarian Academy, Skovorody Str., 1/3, Poltava, 36003, Ukraine.

Tel.:+38-050-851-16-76

E-mail: nazarenko2810@ukr.net
Nazarenko, O.S. (2019). Influence of varroosic invasion on wintering of bee colonies. Scientific Messenger of Lviv National University of Veterinary Medicine and Biotechnologies. Series: Veterinary sciences, 21(94), 184-188. doi: 10.32718/nvlvet9434

Beekeeping belongs to one of the most useful and environmentally friendly traditional economic activities in many countries of the world. This industry provides the population with valuable products, in particular honey - one of the most useful foods that is characterized by therapeutic, bactericidal and dietary properties. Recently, considerable economic damage to the area causes the invasive disease varroosis, which leads to the weakening of the bee colonies, the ability of bees to honey harvest and pollination, sometimes - to their death. The aim of the work was to study the effect of varroosic causative Varroa destructor agent on the wintering of bee colonies. The experimental determination of the degree of life affected bee colonies after wintering varroosic agent for various extensiveness of invasion - weaker (5.30 \pm $0.79 \%)$, average $(15.10 \pm 0.75 \%)$, severe $(32.30 \pm 2.42 \%)$ The main indicators hardiness of bee colonies in the presence of the parasite were-pidmoru weight, the number of ticks in pidmori, the quantity of food in the hive at different periods of hibernation, the percentage of deaths of bee colonies. It has been established that the varroosis negatively affects the course of wintering of bees. Moreover, the quantitative indicators of winter resistance of families depended on the extensiveness of the invasion. At a low intensity of the invasion, the weight of the dormancy of bees after wintering on average was $59.80 \pm 3.34 \mathrm{~g}$, which is 1.2 times $(P<0.01)$ more compared to healthy families. At the same time, 2.0 mice were detected in the dungeon. With an increase in the secretion of bees, the number of dungeons and the number of detected parasites increased significantly. The average length of the invasion showed that the weight of the dormancy of bees was 5.3 times higher $(P<0.001)$ compared with healthy families, and the number of ticks found in dampness was 66.4. Due to the high intensity of the invasion, the weight of the bee dormancy was $1369.10 \pm 49.72 \mathrm{~g}$, which is 28.4 times $(P<0.001)$ more compared to healthy families. The number of detected ticks at such an extensiveness of the invasion amounted to 2,818.3. It has been determined that with the increase of secretion in the process of wintering, bees consumed more food, and this negatively affected their winter resistance. At the same time, due to the strong extensiveness of the invasion, the death of beeeaters after wintering was $80 \%$.

Key words: varroosis, honey bees, extensiveness of invasion, winter resistance of bee colony.

\section{Вплив вароозної інвазії на перебіг зимівлі бджолосімей}

\author{
О.С. Назаренко
}

Полтавська державна аграрна академія, м. Полтава, Украӥна

Бджільництво належить до однієї з найкориснішої та екологічно чистої традиційної господарської діяльності багатьох краӥн світу. Ця галузь забезпечує населення цінними продуктами, зокрема медом - одним з найкорисніших продуктів харчування, який характеризується лікувальними, бактерицидними і дієтичними властивостями. Останнім часом значного економічного збитку галузі завдає інвазійне захворювання варооз, щуо зумовлює ослаблення бджолосімей, зниження здатності бджіл до медозбору $i$ запилення, іноді - до їх загибелі. Метою роботи було вивчити вплив збудника вароозу Vаrroa destruсtor на перебіг зимівлі бджолосімей. Проведено експериментальне визначення ступеню життєдіяльності бджолосімей уражених збудником вароозу після зимів-

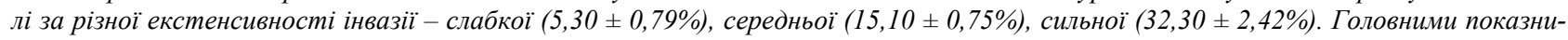


ками зимостійкісті бджолиних сімей за присутності паразита були - вага підмору, кількість кліщів у підморі, кількість корму у вуликах в різні періоди зимівлі, відсоток загибелі бджолосімей. Встановлено, щуо варооз негативно впливає на перебіг зимівлі бджіл. Причому кількісні показники зимостійкісті сімей залежали від екстенсивності інвазії. За слабкої екстенсивності інвазії

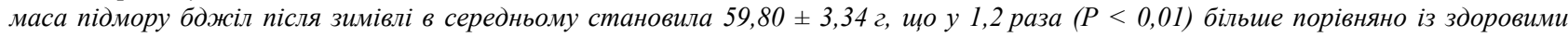
сім'ями. Водночас виявлено у підморі 2,0 екземплярів клішів. Із збільшенням закліщеності бджіл кількість підмору та кількість виявлених паразитів значно зростали. За середньої екстенсивності інвазї маса підмору бджіл виявилася більшою у 5,3 раза ( $P<0,001)$ порівняно із здоровими сім'ями, а кількість кліщів, виявлених у підморі, становила 66, 4 екз. За сильної екстенсивності

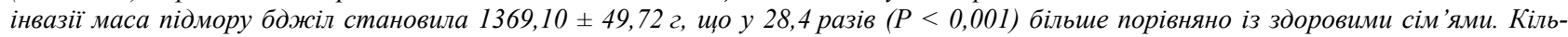
кість виявлених кліщів за такої екстенсивності інвазії сягала 2818,3 екз. Визначено, шчо із збільшенням заклішеності у процесі зимівлі бджоли більше споживали корму, і ие негативно впливало на їх зимостійкість. Одночасно за сильної екстенсивності інвазії загибель бджолосімей після зимівлі становила $80 \%$.

Ключові слова: варооз, медоносні бджсли, екстенсивність інвазіӥ, зимостійкість бджолосімей.

\section{Вступ}

Бджільництво належить до однієї з найкориснішої та екологічно чистої традиційної господарської діяльності багатьох країн світу і, останнім часом, набуває все більшого значення. Це пов'язано, перш за все, з розширенням сфери використання продуктів бджільництва. Водночас медоносних бджіл відносять до найбільш надійних і найкращих обпилювачів ентомофільних культур. Без бджолозапилення неможливо отримати високий врожай якісного насіння конюшини, люцерни, еспарцету та інших кормових трав. Бджолозапилення потребують багато плодових, ягідних і технічних культур, а також рослини закритого грунту. Продукти бджільництва знаходять все більше застосування в медицині і парфумерній промисловості. У фармацевтичній промисловості давно застосовується прополіс, маточне молочко і бджолина отрута. Останнім часом розширюються сфери використання перги і квіткового пилку (Klein et al., 2007; Kito, 2008; Jemec 2012; Calderone, 2012; Affognon et al., 2015; Lopes et al., 2018; Naggar et al., 2018).

Підвищення продуктивності бджільництва та інтенсифікація використання бджіл залежить від умов їх утримання, екологічної ситуації, а також від благополуччя пасік відносно інфекційних та інвазійних захворювань. Останнім часом значного економічного збитку галузі завдає інвазійне захворювання варооз, що зумовлює ослаблення бджолосімей, зниження здатності бджіл до медозбору і запилення, іноді - до їх загибелі (Friesa et al., 2003; Boecking \& Genersch, 2008; Dahle, 2010; Rosenkranz et al., 2010; Le Conte et al., 2010; Nazzi \& Le Conte, 2016).

Збудником інвазії є кліщ Varroa destructor, що паразитує на дорослих бджолах і бджолиному розплоді, живиться їх гемолімфою. Внаслідок цього зменшується тривалість життя медоносних бджіл, знижується розвиток сім'ї, продуктивність і запилююча діяльність. За даними більшості авторів, патогенез вароозу залежить від ступеня інвазії та стану бджолиної сім’ї. Кліщі інтенсивно розмножуються в розплоді, виснажують їх організм та викликають білкове голодування (Moskalenko, 1988; Anderson \& Trueman, 2000; Modin \& Stolbov, 2004; Stiharev, 2010). Клінічно інвазія супроводжується загибеллю лялечок, появою нежиттєздатних бджіл і трутнів (у молодих особин відсутні крила, кінцівки, деформуються груди і черевце). Хвоpi бджоли не можуть злетіти, падають на землю i повзають по території пасіки. Трутні стають нездатними до спаровування 3 матками, їх чисельність різко знижується. Крім того, за вароозу значно скорочується життя медоносних бджіл (Nemkova, 2003; Ignatieva et al., 2004).

Науковцями доведено, що варооз негативно впливає на зимівлю бджіл. При цьому вони занепокоєнні, іноді вилітають 3 вулика, споживають більше корму і частіше гинуть через нестачу корму, аніж внаслідок безпосереднього ураження кліщами. Залежно від співвідношення в сім'ях здорових бджіл і уражених частина їх не доживає до весни, інші - виходять ослабленими. Загибель бджолосімей від вароозу без проведення лікування може сягати 100\% (Akimov et al., 1988; Grobov, 1991; Amdam et al., 2004).

Метою роботи було вивчити вплив збудника вароозу Varroa destructor на перебіг зимівлі бджолосімей.

\section{Матеріал і методи досліджень}

\section{Дослідження проводилися упродовж}

2016-2018 pр. на базі приватної пасіки Гребінківського району Полтавської області. Паразитологічні дослідження проводили в лабораторії кафедри паразитології та ветеринарно-санітарної експертизи факультету ветеринарної медицини Полтавської державної аграрної академії.

Для дослідів використовували сім'ї аналоги, які обсиджували шість рамок. Було сформовано три дослідних і одну контрольну групи бджолосімей по 10 вуликів у кожній. Дослідні групи сімей мали різну екстенсивність вароозної інвазії - слабку (до 10\%), середню (11-20\%), сильну (понад 20\%). Контрольна група бджолосімей була вільною від $V$. destructor.

3 метою визначення закліщеності бджолосімей перед формуванням сім’ї на зимівлю відбирали 100 живих бджіл та досліджували згідно загальноприйнятої методики (1984). Кількість кліщів у підморі визначали із застосуванням соняшникової олії (Peroutka et al., 1981). Витрату корму бджолами за зимовий період визначали за кількістю меду у гніздах восени та ранньою весною згідно методики, де умовно рахується, що вага 1 дм³ меду дорівнює 300 г (Borodachev, 2006).

Математичний аналіз отриманих даних проводили 3 використанням пакета прикладних програм Microsoft "EXCEL" шляхом визначення середнього арифметичного (M), його похибки (m) та рівня вірогі- 
дності (Р) 3 використанням таблиці $\mathrm{t}$-критеріїв Стьюдента.

\section{Результати та їх обговорення}

Проведеними дослідженнями встановлено, що варооз негативно впливає на зимівлю бджіл. Причому кількісні показники зимостійкості сімей залежали від екстенсивності інвазії (табл. 1, рис. 1, а, б).

Так, за слабкої екстенсивності інвазії - 5,30 \pm 0,79\% маса підмору бджіл після зимівлі в середньому становила 59,80 \pm 3,34 г (за коливань від 43 до 75 г), що у 1,2 раза $(\mathrm{P}<0,01)$ більше порівняно із здоровими сім'ями. Водночас виявлено у підморі $2,0 \pm 0,30$ екземплярів кліщів за коливань від 1 до 4 екз. Із збільшенням закліщеності бджіл маса виявленого підмору значно збільшувалася. За середньої екстенсивності вароозної інвазії $(15,10 \pm 0,75 \%)$ маса підмору бджіл становила в середньому $256,70 \pm 25,77$ г (за коливань від 145 до 380 г), що у 5,3 раза $(\mathrm{P}<0,001)$ більше порівняно із здоровими сім'ями, а кількість кліщів, виявлених у підморі, становила $66,40 \pm 9,19$ екз. (за коливань від 7 до 68 екз.).

\section{Таблиця 1}

Показники зимостійкості бджолосімей уражених збудником вароозу залежно від екстенсивності інвазії, $\mathrm{M} \pm \mathrm{m}(\mathrm{n}=10)$

\begin{tabular}{|c|c|c|c|c|c|c|c|}
\hline \multirow{2}{*}{\multicolumn{2}{|c|}{$\begin{array}{l}\text { Група / ступінь } \\
\text { інвазованості }\end{array}$}} & \multirow{2}{*}{$\begin{array}{l}\text { EI, } \\
\%\end{array}$} & \multirow{2}{*}{$\begin{array}{c}\text { Вага бджіл у } \\
\text { підморі, г }\end{array}$} & \multirow{2}{*}{$\begin{array}{c}\text { Кількість кліщів у } \\
\text { підморі, екз. }\end{array}$} & \multicolumn{2}{|c|}{ Кількість корму, кг } & \multirow{2}{*}{$\begin{array}{l}\text { Загибель } \\
\text { сімей, \% }\end{array}$} \\
\hline & & & & & восени & навесні & \\
\hline \multirow{3}{*}{ дослідні } & слабка & $5,30 \pm 0,79$ & $59,80 \pm 3,34 * *$ & $2,0 \pm 0,30$ & $18,30 \pm 0,10$ & $8,20 \pm 0,19 * *$ & - \\
\hline & середня & $15,10 \pm 0,75$ & $256,70 \pm 25,77 * * *$ & $66,40 \pm 9,19$ & $18,49 \pm 0,14$ & $7,38 \pm 0,15^{* * *}$ & - \\
\hline & сильна & $32,30 \pm 2,42$ & $1369,10 \pm 49,72 * * *$ & $2818,30 \pm 530,67$ & $18,42 \pm 0,15$ & $11,65 \pm 0,35 * * *$ & 80 \\
\hline \multicolumn{2}{|c|}{ контрольна } & - & $48,20 \pm 1,27$ & - & $18,69 \pm 0,13$ & $9,03 \pm 0,15$ & - \\
\hline
\end{tabular}

Примітка: **-P <0,01; ***-P <0,001 - відносно показників контрольної групи сімей бджіл

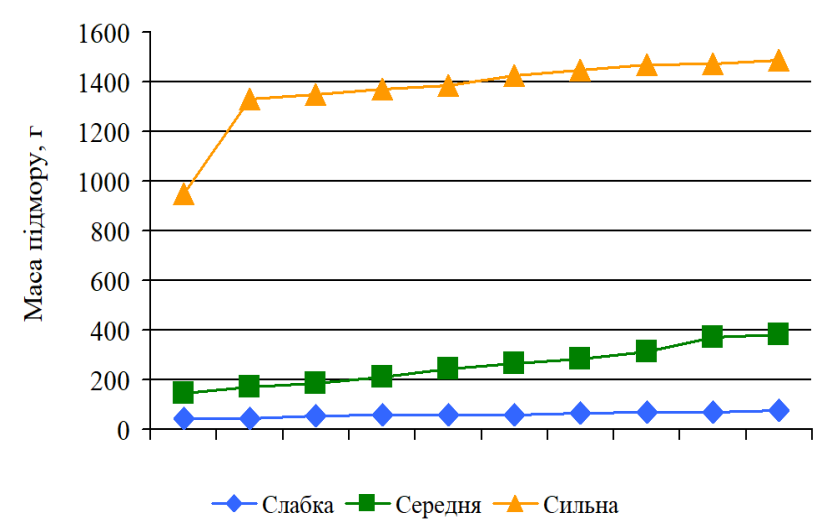

a

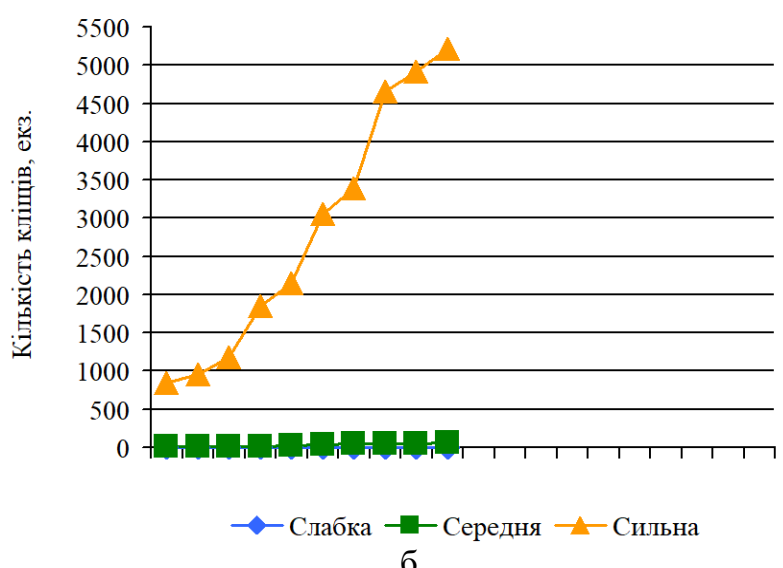

6

Рис. 1. Показники маси підмору бджіл (а) та кількості виявлених Varroa destructor (б) залежно від екстенсивності інвазії

За сильної екстенсивності інвазії $(32,30 \pm 2,42 \%)$ маса підмору бджіл становила $1369,10 \pm 49,72$ г за коливань від 950 до 1488 г, що у 28,4 разів $(\mathrm{P}<0,001)$ більше порівняно із здоровими сім'ями. Кількість виявлених кліщів за такої екстенсивності інвазії сягала $2818,30 \pm 530,67$ екз. за коливань від 840 до 5220 екз. Одночасно за таких показників закліщеності бджолосімей їх загибель після зимівлі спостерігали 3 15 листопада до 20 січня, сягала $80 \%$. В результаті дослідження загиблих бджолосімей всі бджоли були осипані (рис. 2).

Водночас, за результатами визначення кількості корму, що був використаний бджолами в період зимівлі, встановлено збільшення його споживання у сім'ях за слабкої та середньої екстенсивності інвазії. Так за слабкої EI $(5,30 \pm 0,79 \%)$ кількість корму, що залишився у вулику після зимівлі становила, в середньому 8,20 $\pm 0,19$ кг, що на 9,2\% (P < 0,01) менше, ніж

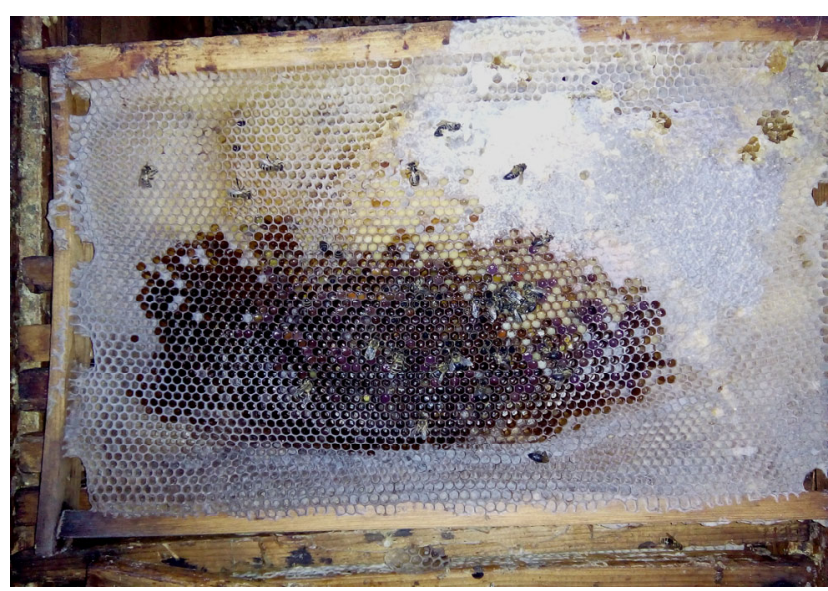

Рис. 2. Рамки загиблих бджолосімей уражених збудником вароозу після зимівлі за сильного ступеня екстенсивності інвазії у здорових сім'ях $(9,03 \pm 0,15$ кг). 
За середньої ЕI $(15,10 \pm 0,75 \%)$ кількість корму після зимівлі виявилася ще меншою (на 18,3\%, Р < 0,001) порівняно зі здоровими сім'ями. За сильної ЕI $(32,30 \pm 2,42 \%)$ кількість корму становила $11,65 \pm 0,35$ кг, що на 22,5\% (Р < 0,001) більше, ніж у здорових бджолосімей, що пов'язано із високою загибеллю сімей внаслідок вароозу.

Аналізуючи отримані дані можна зазначити, що більшість наукових праць присвячено вивченню особливостей поширення вароозу бджіл у різних кліматичних зонах, а також адаптації медоносної бджоли до V. destructor (Anderson \& Trueman, 2000; Modin \& Stolbov, 2004; Nazzi \& Le Conte, 2016). Однак встановленню особливостей впливу збудника вароозу на зимівлю бджіл залежно від екстенсивності інвазії присвячені лише окремі праці (Kirjushin, 2007).

Результатами проведених досліджень встановлена залежність показників зимостійкості бджолосімей від екстенсивності вароозної інвазії. Із зростанням ЕI після зимівлі збільшується маса підмору бджіл у 1,228,4 разів $(\mathrm{P}<0,01 \ldots \mathrm{P}<0,001)$ порівняно із здоровими сім'ями. Водночас у підморі зростає кількість виявлених кліщів, в середньому від 2,0 екз. (за слабкої ЕI) до 2818,30 екз. (за сильної ЕI). Виявлено, що за слабкої та середньої ЕІ збільшується кількість спожи-

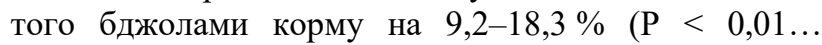
$\mathrm{P}<0,001)$ порівняно із здоровими сім'ями. На нашу думку, це пов'язане із занепокоєнням бджіл у вулику внаслідок подразнення їх збудником. За сильної ЕI виявлено загибель 80\% бджолосімей, що обумовлювало наявність більшої кількості корму (на 22,5\%, $\mathrm{P}<0,001)$ після їх зимівлі.

Окремі автори зазначають про зв'язок між гігієнічними здатностями, темпами збільшення популяції вароа, зимостійкістю бджолиних сімей, особливостями медоносної бджоли як сільськогосподарської комахи та розвитком резистентності медоносної бджоли до паразитування V.destructor (Kirjushin, 2005; Akimov \& Kirjushin, 2008).

\section{Висновки}

Варооз медоносних бджіл негативно впливає на перебіг зимівлі бджолосімей, де показники їх зимостійкості залежать від екстенсивності інвазії. Із збільшенням закліщеності бджіл достовірно зростає маса підмору та кількість виявлених у ньому кліщів. За слабкої та середньої екстенсивності інвазії у період зимівлі збільшується споживання бджолами корму, внаслідок їх занепокоєння та негативного впливу Varroa destructor. За високої екстенсивності інвазії загибель сімей після зимівлі сягає 80 \%, наступає на початку зимівлі до 20 січня, що є характерною ознакою вароозу.

Перспективи подальших досліджень. Проведені дослідження обумовлюють необхідність визначення терапевтичної ефективності сучасних лікарських засобів за вароозу бджіл.

\section{References}

Affognon, H.D., Kingori, W.S., Omondi, A.I., Diiro, M.G., Muriithi, B.W., Makau, S., \& Raina, S.K. (2015). Adoption of modern beekeeping and its impact on honey production in the former Mwingi District of Kenya: assessment using theory-based impact evaluation approach. International journal of tropical insect science, 35(2), 96-102. doi: 10.1017/S1742758415000156.

Akimov, I.A., \& Kirjushin, V.E. (2008). Vozmozhnye puti adaptacii Apis mellifera (Hymenoptera, Apidae) k parazitirovaniju kleshha Varroa destructor. Vestnik zoologii, 42(3), 237-247 (in Russian).

Akimov, I.A., Starovir, I.S., Jastrebcov, A.V., \& Gogol, V.T. (1988). Kleshh Varroa - vozbuditel varoatoza pchel: morfologicheskij ocherk. Kyiv: Naukova dumka (in Russian).

Amdam, G.V., Hartfelder, K., Norberg, K., Hagen, A., \& Omholt, S.W. (2004). Altered Physiology in Worker Honey Bees (Hymenoptera: Apide). Infested with the Mite Varroa destructor (Acari: Varroide): a factor in colony loss during overwintering? Journal of Economic Entomology, 97(3), 741-747. doi: 10.1093/jee/97.3.741.

Anderson, D.L., \& Trueman, J.H.W. (2000). Varroa jacobsoni (Acari: Varroida) is more than one species. Experimental \& Applided Acarology, 24, 165-189. https://www.ncbi.nlm.nih.gov/pubmed/11108385.

Boecking, O., \& Genersch, E. (2008) Varroosis - the ongoing crisis in bee keeping. Journal für Verbraucherschutz und Lebensmittelsicherheit, 3, 221-228. doi: 10.1007/s00003-008-0331-y.

Borodachev, A.V. (2006). Metody provedenija nauchnoissledovatelskih rabot $\mathrm{V}$ pchelovodstve: uchebnoe posobie. Rybnoe: NIIP (in Russian).

Calderone, N.W. (2012). Insect pollinated crops, insect pollinators and US agriculture: trend analysis of aggregate data for the period 1992-2009. PLOS One, 7, e37235. doi: 10.1371/journal.pone.0037235.

Dahle, B. (2010). The role of Varroa destructor for honey bee colony losses in Norway. Journal of apicultural research \& bee world, 49, 124-125. doi: 10.3896/IBRA.1.49.1.26.

Friesa, I., Hansenb, H., Imdorfc, A., \& Rosenkranzd, P. (2003). Swarming in honey bees (Apis mellifera) and Varroa destructor population development in Sweden. Apidologie, 34, 389-397. doi: 10.1051/apido:2003032.

Grobov, O.F. (1991). Varrooz. Kleshhi: parazityt pchel i vrediteli ih produkcii. Moskva (in Russian).

Ignatieva, G.I., Melnik, V.N., Sohlikov, A.B., \& Muravskaja, O.I. (2004). Taktika borby s varroatozom pchel. Pchelovodstvo, 1, 32-34 (in Russian).

Jemec, K.I. (2012). Ocinka zabezpechenosti bdzholynymy sim'jamy povnocinnogo zapylennja osnovnyh entomofilnyh kultur. Visnyk Poltavskoi derzhavnoi agrarnoi akademii, 4, 61-64. doi: 10.31210/visnyk2012.04.15 (in Ukrainian).

Kirjushin, V.E. (2007). Zimostojkost' pchelinyh semej Apis mellifera (Hymenoptera, Apidae) i ih gigienicheskie sposobnosti. Dostizhenija jentomologii 
na sluzhbe agropromyshlennogo kompleksa, lesnogo hozjajstva i mediciny, 93-94 (in Russian).

Kirjushyn, V.Je. (2005). Zalezhnist' grumingovyh reakcij bdzhil vid temperatury, vzjatku, najavnosti klishhiv V. destructor. Vestnyk zoologyy, 19(1), 173-175 (in Ukrainian).

Kito, H. (2008). Establishment of sweets society in Japan: premodern sugar supply. Sophia Economic Review, $53,45-61$.

Klein, A.-M., Vaissière, B.E., Cane, J.H., SteffanDewenter, I., Cunningham, S.A., Kremen, C., \& Tscharntke, T. (2007). Importance of pollinators in changing landscapes for world crops. Proceedings of the Royal Society B: Biological Sciences, 274, 303 313. doi: 10.1098/rspb.2006.3721.

Le Conte, Y., Ellis, M., \& Ritter, W. (2010). Varroa mites and honey bee health: can Varroa explain part of the colony losses? Apidologie, 41, 353-363. doi: 10.1051/apido/2010017.

Lopes, M., Falcão, S., Dimou, M., Thrasyvoulou, A., \& Vilas-Boas, M. (2018). Impact of traditional and modern beekeeping technologies on the quality of honey of Guinea-Bissau. Journal of Apicultural Research, 57(3), 406-417. doi: 10.1080/00218839.2018.1430979.

Metodicheskie ukazanija po jekspress-diagnostike varroatoza i opredeleniju stepeni porazhenija pchelinyh semej kleshhami varroa v uslovijah paseki. Utverzhdeny Glavnym upravleniem veterinarii Ministerstva sel'skogo hozjajstva SSSR Prikazom № 115-6k ot 16.01.1984 (in Russian).
Modin, O.A., \& Stolbov, N.M. (2004). Materialy po epizootologii varrooza pchel $\mathrm{v}$ Tjumenskoj oblasti. Trudy VNII veterinarnoj entomologii i arahnologii, 46, 58-61 (in Russian).

Moskalenko, P.G. (1988). Neobratimaja sterilnost perezimovavshih pchel. Pchelovodstvo, 3, 9-10 (in Russian).

Naggar, Y., Codling, G., Giesy, J.P., \& Safer, A. (2018). Beekeeping and the Need for Pollination from an Agricultural Perspective in Egypt. Bee World, 95(4), 107-112. doi: 10.1080/0005772X.2018.1484202.

Nazzi, F., \& Le Conte, Y. (2016). Ecology of Varroa destructor, the major ectoparasite of the western honey bee, Apis mellifera. Annual Review of Entomology, 61, 417-432. doi: 10.1146/annurev-ento010715-023731.

Nemkova, S.N. (2005). Sezonnaja dinamika jekstensivnosti zarazhenija imago pchel Apis mellifera kleshhom Varroa (Parasitiformes, Varroidae) v raznyh regionah Ukrainy. Vestnik zoologii, 39(4), 73-78 (in Russian).

Peroutka, M., Titerova, Ja., \& Haklova, M. (1981). Rannij diagnoz varoatoza s pomoshh'ju ul'evogo podmora. Apiakta, 3, 119-120 (in Russian).

Rosenkranz, P., Aumeier, P., \& Ziegelmann, B. (2010). Biology and control of Varroa destructor. Journal of Invertebrate Pathology, 103, 96-119. doi: 10.1016/j.jip.2009.07.016.

Stiharev, I. (2010). Varroatoz. Veterinarija selskohozjajstvennyh zhivotnyh, 1, 15-19 (in Russian). 